\title{
MAKNA DIALOG YESUS DENGAN FILIPUS DALAM YOHANES 14: 8-14
}

\author{
Yusuf L. M \\ Sekolah Tinggi Teologi Injili Setia Siau \\ yusufmarriba2@gmail.com
}

\begin{abstract}
The text of John 14: 8-14 shows the confusion and failure of disciples to understand Jesus's teaching. This is in contrast to the situation of the disciples closeness to Jesus. They should have understood Jesus' intentions faster because they had been living with Jesus for a long time in the ministry. On the contrary, this dialogue actually shows as if there was a huge dividing wall between Jesus and the disciples. The main factor that prevented disciples from understanding Jesus' teaching was that the disciples did not yet truly believe the authority that Jesus had. The disciples are still bound by the OT conceptual understanding of how to see the Father through Theophany revelation. Therefore, this article examines the meaning contained in the dialogue by conducting an exegesis analysis of each word and phrase to find the main message that is emphasized in the text.
\end{abstract}

Keywords: Dialogue, Jesus, Philip, John 14: 8-14

\begin{abstract}
Abstrak. Teks Yohanes 14: 8-14 memperlihatkan adanya kebingungan dan kegagalan para murid memahami pengajaran Yesus. Hal ini bertolak belakang dengan situasi kedekatan para murid dengan Yesus. Seharusnya mereka lebih cepat memahami maksud Yesus karena mereka sudah lama hidup bersama Yesus dalam pelayanan. Namun sebaliknya dalam dialog ini justru memperlihatkan seperti adanya sebuah tembok pemisah yang sangat besar antara Yesus dengan para murid. Faktor utama yang menjadi penghalang para murid gagal memahami pengajaran Yesus adalah para murid belum percaya sungguh-sungguh otoritas yang dimiliki oleh Yesus. Para murid masih terikat dengan konsep pemahaman PL tentang cara melihat Bapa melalui penyataan yang bersifat Theofany. Oleh sebab itu, artikel ini berupaya mengkaji makna yang terkandung di dalam dialog tersebut dengan cara melakukan analisis eksegesis terhadap setiap kata dan frasa untuk menemukan pesan utama yang ditekankan di dalam teks.
\end{abstract}

Kata-kata Kunci: Dialog, Yesus, Filipus, Yohanes 14: 8-14

Teks Yohanes 13:21 -14: 1-7 merupakan rangkaian dari peristiwa percakapan antara Yesus dengan para murid di meja makan, yang biasa disebut dengan percakapan perpisahan. Leon-Dufour menjelaskan, seperti yang dikutip oleh Houwelingen bahwa, "meskipun banyak naskah mengawali apa yang disebut percakapan perpisahan itu pada $14: 1$, tetapi 
dalam 14:1-3, teka-teki dari 13:33 dipecahkan melalui pertanyaan Petrus." (Houwelingen, 1997, p. 1). Jadi mulai dari 13:21-14 :1-31 merupakan bagian dari satu kronologi peristiwa yang sebenarnya tidak dapat dipisahkan. Ridderbos menganggapnya "sebagai bagian dari percakapan atau perjanjian perpisahan Yesus yang besar dengan para murid-Nya di mulai pasal 14-16, yang kemudian pada puncaknya diakhiri dengan doa Yesus sebagai imam besar di pasal 17." (Ridderbos, 2012, p. $523)$.

Hal yang menjadi pokok awal perdebatan dalam teks ini dimulai dari permintaan Filipus, "Tuhan, tunjukkanlah Bapa itu kepada kami." Permintaan ini tampaknya mewakili kegagalan para murid dalam memahami pengajaran Yesus karena Filipus menggunakan kata ganti jamak "kami." Hal ini dianggap gagal karena Tomas dalam dialog kedua sudah menunjukkan ketidaktahuannya, namun Filipus dalam dialog ketiga masih meminta Bapa ditunjukkan kepada mereka. Seharusnya para murid sudah bisa mengerti maksud Yesus karena dalam ayat $7 \mathrm{a}$ Yesus sudah memberi syarat mutlak untuk mengenal Bapa "sekiranya kamu mengenal Aku, pasti kamu mengenal Bapa-Ku." Para murid bukannya menunjukkan pengetahuan yang benar tentang Yesus, justru sebaliknya. Dengan penggunaan kata dalam bentuk subjunktif dalam kalimat pertama memperlihatkan kegagalan para murid dalam memahami secara benar tentang Yesus dan penggunaan subjunktif yang kedua 
memperlihatkan suatu syarat utama untuk memahami Bapa (Ridderbos, 2012, p. 537).

Penelitian ini berupaya untuk mengkaji faktor apa yang menyebabkan Filipus mengajukan pertanyaan kepada Yesus dan apa akibat dari dialog tersebut serta makna apa yang terkandung dalam jawaban Yesus dalam upaya menjawab kegagalan pemahaman para murid dalam memahami maksud Yesus.

\section{METODE}

Penelitian ini merupakan kajian literatur teks Alkitab terhadap teks Yohanes 14:8-14. Pendekatan yang digunakan adalah kualitatif dengan metode deskriptif analisis teks. Hal yang dideskripsikan adalah konteks Yohanes 14:8-14 dengan analisis gramatikal teks sesuai dengan prinsipprinsip eksegesis untuk mendapatkan makna yang terkandung dalam dialog antara Yesus dengan Filipus. Analisis artinya menguraikan suatu pokok atas berbagai bagiannya supaya memperoleh pengertian yang tepat dan arti secara keseluruhan (Sutanto, 2000). Penelitian ini juga disebut deskriptif karena berusaha mendeskripsikan atau menginterpretasikan akibat yang sedang terjadi atau kecenderungan yang berkembang. Eksegesis adalah menggali arti dari bahasa asli sesuai maksud penulis Kitab Suci dalam konteks aslinya (O'Collins, Farrugia, \& Suharyo, 1996). 


\section{HASIL}

Penyebab utama Filipus gagal memahami pengajaran Yesus adalah belum sepenuhnya memahami secara benar otoritas Yesus. Hal ini membuatnya ingin melihat Bapa secara langsung seperti Theofany dalam Perjanjian Lama yang merupakan bentuk kelemahan iman dan ketidaktahuan Filipus dan para murid lainnya terhadap penyataan Allah melalui Yesus. Ungkapan Yesus 'Aku di dalam Bapa dan Bapa di dalam Aku' memberi penegasan bahwa Bapa dan Anak adalah satu esensi sebagai Allah. Hal ini diungkapkan Yesus untuk menjawab keraguan para murid menjelang kenaikannya ke sorga. Dalam ayat 11 Yesus sangat tegas menyatakan bahwa diri-Nya adalah Allah sendiri. Jadi dengan melihat Dia berarti sudah melihat Bapa.

Cara lain Yesus menunjukkan otoritas-Nya kepada para murid adalah melalui hal pengabulan doa. Yesus menegaskan bahwa "mintalah dalam namaKu, Aku akan melakukannya". Cara ini dimaksudkan supaya para murid mengerti dengan benar dan percaya dengan benar bahwa Yesus memiliki otoritas yang sama dengan Bapa. Jadi apabila sudah melihat Anak maka tidak perlu memaksakan kehendak untuk melihat penyataan seperti theofany PL karena penyataan Allah yang sempurna sudah jelas ada di hadapan mereka.

Penegasan Yesus sebagai Allah semakin jelas melalui frasa "Aku akan melakukannya." Ini membuktikan bahwa Dia adalah Allah yang akan menjawab setiap doa para murid sekaligus menegaskan bahwa semua Yusuf L.M 
yang dilakukan Yesus supaya Bapa-Nya di Sorga dipermuliakan di dalam nama-Nya. Jadi, secara keseluruhan dalam konteks ini seharusnya Filipus dan para murid tidak memiliki keraguan untuk percaya sepenuhnya kepada Yesus karena Dia adalah Allah itu sendiri.

\section{PEMBAHASAN}

\section{Permintaan Filipus (Ayat 8)}

Teks ini diawali dengan permintaan Filipus kepada Yesus, yang merupakan reaksi pembicaraan dalam dialog pertama yakni pertanyaan Petrus mengenai "Yesus akan pergi ke mana?" dan dialog kedua yakni pertanyaan Tomas tentang "ketidaktahuan mereka atas penjelasan Yesus mengenai rumah Bapa". Kedua dialog itu yang memunculkan pertanyaan Filipus kepada Yesus yakni "Tuhan, tunjukkanlah Bapa itu kepada kami, itu sudah cukup bagi kami”. Penekanan kata $\delta \epsilon \grave{\iota} \xi o \nu$ bentuk orang kedua, tunggal, imperatif, aorist, aktif dari kata $\delta \epsilon i \kappa \nu \nu \mu \iota ~ y a n g ~ a r t i n y a$ memperlihatkan atau menunjukkan. Penggunaan kata ini menunjukkan suatu penegasan permintaan Filipus terhadap Yesus. Menurut Van Houwelingen bahwa, "Ada dua kemungkinan perumusan tentang frasa ini pertama: ada kemungkinan perumusan ini menunjukkan adanya sedikit keraguan. kedua: permintaan atau usulan Filipus itu juga dapat timbul dari rasa hormat yang tulus kepada Yesus sebagai Anak Bapa." (Houwelingen, 1997, p. 5) 
Makna frasa permintaan Filipus bisa mengacu kepada sifat keraguan para murid dalam hal kepercayaan, tetapi juga acuan yang lebih dalam mengarah kepada pengertian Perjanjian Lama (PL). Penekanan mengenai acuan kepada PL juga ditekankan oleh Morris dengan menyatakan bahwa,

Perkataan tentang melihat Bapa memberi kesan kepada Filipus bahwa melihat keperkasaan Bapa secara nyata itu sangat susah. Karena itu dia berkata kepada Yesus supaya dinyatakan kepadanya tentang Bapa, hal ini dia menghubungkannya dengan theofany yang sering ditemukan di dalam PL (Kel.24:10; 33:17). (Morris, 1992, p. 571).

Di dalam PL memang ada beberapa contoh theofany. Salah satunya adalah peristiwa Musa di gunung Sinai (Kel.33:18-23), di mana Musa meminta kepada Allah supaya memperlihatkan kemuliaan-Nya kepada dia, namun Allah hanya memperlihatkan belakang-Nya. (Carson, 2000).

Dengan keinginan tersebut, Filipus telah gagal memahami kemuliaan di dalam Yesus, anugerah, dan kebenaran Allah (BeasleyMurray, 1999). Keinginan itu juga semakin memperjelas kelemahan atau kegagalannya memahami Yesus sebagai wujud nyata penyataan Allah secara sempurna. Yesus agak kesal dengan permintaan Filipus itu. la pun menjawab bahwa jika mereka tidak percaya kepada-Nya, maka mereka dapat percaya melalui perkataan dan pekerjaan-Nya (ay.9-10). (Blomberg, 2002; Ridderbos, 2012).

Dengan demikian dapat disimpulkan bahwa makna permintaan Filipus itu tulus adanya karena memang ada rujukannya dalam Perjanjian 
Lama, tapi juga sekaligus memperlihatkan kelemahan iman dan ketidaktahuan mereka terhadap penyataan Allah melalui Yesus. Hal ini terlihat dari penggunaan kata $\delta \epsilon \hat{\imath} \xi o \nu$ dalam bentuk imperatif yakni 'tunjukkanlah atau perlihatkanlah.' Kata ini memperlihatkan sikap Filipus yang mendesak Yesus supaya diperlihatkan Bapa kepada mereka. Bruce juga menekankan bahwa "saat itu, Filipus mengungkapkan iman para murid yang masih mencari-cari kebenaran" (Bruce, 2013, p. 313). Ada kerinduan di hati para murid untuk melihat kemuliaan Allah secara sempurna. Namun itu tidak menjadi standar bagi Filipus dan para murid bahwa mereka sungguh-sungguh beriman. Penekanan ini muncul dari penggunaan kata $\alpha_{\alpha}^{\rho} \kappa \epsilon \hat{\iota}$ (orang, ketiga, tunggal, indiktif, present, aktif dari kata $\alpha ́ \rho \kappa \epsilon ' \omega$. yang artinya "cukup" atau "menjadi kuat" (Rienecker, 1980, p. 251). Ini memperlihatkan bahwa mereka sama sekali tidak memahami maksud Yesus. Mereka berpikir dengan melihat Allah dalam bentuk seperti itu sudah cukup untuk percaya. Mereka lupa bahwa mereka sudah hidup bersama Yesus. Itu seharusnya sudah cukup bagi mereka untuk percaya dengan sungguh-sungguh (Henry, 2010).

\section{Reaksi Yesus terhadap Permintaan Filipus (Ayat 9)}

Pada bagian ini terlihat jawaban dan reaksi Yesus terhadap

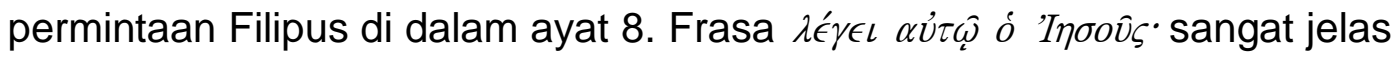
bahwa Yesus pertama-tama berbicara secara khusus kepada Filipus. Hal itu terlihat dari kata $\alpha \dot{v} \tau \omega \hat{\jmath}$ dalam bentuk datif tunggal yang menunjukkan 
bahwa Yesus berbicara kepada satu pribadi yakni Filipus. Dalam hal ini, Yesus tidak berbicara langsung kepada para murid (dalam bentuk jamak) tetapi kepada Filipus (bentuk tunggal). Filipus telah gagal mendengarkan dengan baik perkataan yang disampaikan kepada Tomas tentang pengajaran bahwa Bapa telah hadir di dalam Anak (Hendriksen \& Kistemaker, 2007). Dialog yang kedua, Filipus dianggap gagal memahami dan mengerti pengajaran Yesus ketika menjawab pertanyaan Tomas (ay.5-7) mengenai pernyataan Yesus "sekiranya kamu mengenal Aku, pasti kamu juga mengenal Bapa-Ku". Hal yang sama ditekankan Henry bahwa ketika pertama kali berjumpa dengan-Nya, Filipus menyatakan bahwa ia tahu Kristus adalah sang Mesias (1: 45), namun sampai saat ini ia tidak mengenal Bapa di dalam Dia (Henry, 2010). Jadi dapat dipahami bahwa Yesus menjawab secara khusus kepada Filipus karena dia dianggap telah gagal memahami Yesus dengan benar, pada hal dia sudah satu tahun menjadi murid Yesus. Dia juga gagal mengulangi pengakuannya pada waktu dia dipanggil menjadi rasul (1:45).

Penekanan penting yang perlu diperhatikan di dalam teks ini adalah

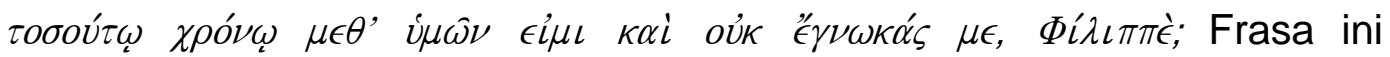
menekankan kata tosou,tw (datif, tunggal, maskulin dari kata toбov̂tos. yang bisa diartikan "begitu besar, begitu banyak". Ini menjelaskan perkataan Yesus yakni "waktu yang panjang" (Rienecker, 1980, p. 251). Kata $\tau o \sigma o u ́ \tau \omega$ dapat menjelaskan bahwa Filipus dan para murid yang lain, 
sudah banyak mempunyai waktu bersama Yesus namun mereka belum memahami Yesus dengan benar. (Carson, 2000, p. 494). Dengan

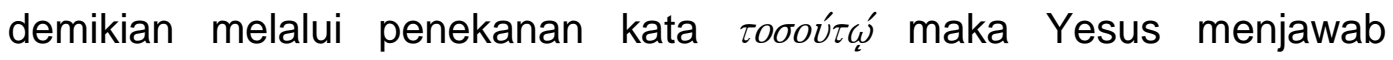
pertanyaan Filipus dengan mengarahkan semua penjelasan kepada para murid, meskipun dalam penjelasan itu, Yesus juga menegur Filipus secara khusus. Hal ini dipertegas dalam penjelasan Hendriksen bahwa,

Yesus memberikan teguran halus ketika Dia mengatakan "telah sekian lama Aku bersama-sama kamu, namun engkau tidak mengenal Aku?" Dalam hal ini kata you dalam bentuk jamak dan juga you dalam bentuk tunggal "engkau tidak mengenal Aku?" Dalam bentuk jamak menunjuk kepada semua murid yang hadir di ruangan atas dan bentuk tunggal menunjuk kepada Filipus sendiri (Hendriksen \& Kistemaker, 2007, p. 270).

Pengajaran Yesus dalam bentuk teguran halus itu ditujukan kepada semua murid, tetapi penekanan bentuk tunggal jelas ditujukan kepada Filipus.

Yesus mulai menjelaskan tentang diri-Nya dengan menekankan bahwa Dia dengan Bapa adalah satu. Dia menggunakan tiga tense perfect

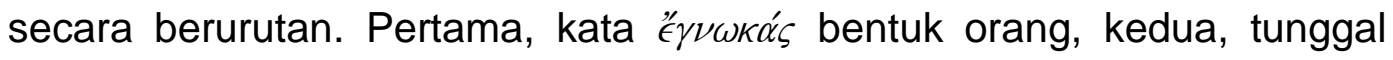
indikatif perfect aktif dari kata $\gamma\llcorner\nu \omega \sigma \kappa \omega$ artinya mengenal. Kedua kata $\delta$ $\dot{\epsilon} \omega \rho \alpha \kappa \omega$ s bentuk nominative tunggal maskulin partisip perfect aktif dari kata

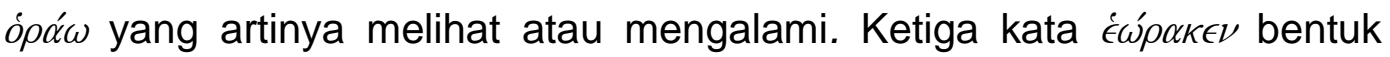
orang ketiga tunggal indikatif perfect aktif dan juga berasal dari kata óóá Ketiga kata tersebut menekankan pengetahuan spiritual dan menekankan bahwa ketidakmungkinan penebusan dinyatakan terpisah dari Kristus, 
karena Allah menyatakan diri-Nya secara sempurna di dalam Kristus (Hendriksen \& Kistemaker, 2007). Ketiga tense perfect itu memberi pemahaman kepada para murid bahwa dengan melihat dan mengenal Yesus berarti sama dengan melihat dan mengalami kehadiran Bapa. Barclay menegaskan, jawaban Yesus tersebut sama yang diberikan kepada Yohanes Pembaptis ketika dia mengirim utusannya untuk menanyakan apakah benar Yesus itu Mesias (Mat.11:1-6), dan Yesus menjawab mereka "katakanlah kepada Yohanes apa yang kamu dengar dan kamu lihat" (Barclay, 1996). Yesus secara tegas menyatakan diri-Nya adalah kebenaran. Köstenberger menekankan bahwa persekutuan Yesus dengan Bapa dinyatakan dalam dua tindakan yaitu melalui Firman (pengajaran-Nya) dan melalui pekerjaan-Nya, hal ini menjadi tanda bagi para murid (Köstenberger, 2004). Jadi seharusnya para murid sudah mengerti dengan benar bahwa Yesus itu adalah Allah sendiri karena mereka sudah lama bersama-sama dengan Yesus.

\section{Yesus menjadi Bukti Kehadiran Bapa (Ayat 10)}

Pada ayat 10 Yesus menekankan kesatuan antara Anak dan Bapa. Menurut Carson, pertanyaan Yesus mengenai 'tidak percayakah engkau...?" menunjukkan bahwa para murid seharusnya percaya bahwa Yesus ada di dalam Bapa dan Bapa di dalam Dia, suatu persekutuan yang sempurna antara Yesus dan Bapa (Carson, 2000). 
Makna perkataan tersebut bukan hanya 'tinggal bersama-sama', tapi pekerjaan Yesus adalah pekerjaan Bapa-Nya (10:37) (Michaels, 2010). Yesus tidak berbicara berdasarkan gelar pribadi-Nya melainkan Dia merupakan pengantara dari Bapa-Nya (Houwelingen, 1997). Ungkapan 'Aku di dalam Bapa dan Bapa di dalam Aku' memberi penegasan bahwa Bapa dan Anak adalah satu esensi, yaitu dalam semua atribut-Nya adalah Allah" atau Yesus satu esensi dengan Bapa yang adalah Allah (Hendriksen \& Kistemaker, 2007). Ketika Yesus berbicara kepada para murid sama dengan Allah sendiri yang berbicara kepada para murid. Tenney menyatakan, "penegasan yang demikian, menuntut bukti, dan Yesus memberikannya. la meminta Filipus untuk percaya pertama karena kepribadian-Nya, kedua kehadiran Bapa di dalam Yesus sepanjang waktu merupakan suatu kesaksian tentang kesatuan antara Bapa dan diri-Nya”. (Tenney, 1996, p. 210). Kehadiran-Nya di dalam dunia menjadi bukti yang nyata bagi para murid bahwa dengan melihat Yesus sama dengan melihat Bapa.

\section{Penegasan Yesus: Percayalah Kepada-Ku (Ayat11)}

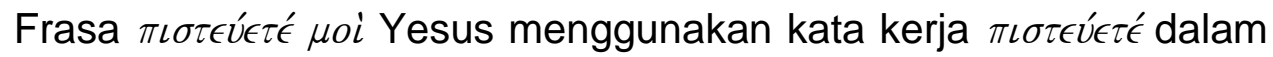
bentuk orang kedua jamak imperatif aktif dari kata $\pi \iota \sigma \tau \epsilon u ́ \omega ́$ artinya 'percayalah'. Kata kerja bentuk jamak ini, memberi pengertian bahwa Yesus menegaskan perkataan tersebut kepada semua murid-Nya (Houwelingen, 1997). Perkataan ini berpusat kepada diri Yesus bahwa Dia 
adalah Allah itu sendiri. Kalau sudah bertemu dengan Dia sama dengan bertemu dengan Allah. Frasa 'percayalah kepada-Ku' di dalam konteks ini, tidak hanya diartikan trust me, tetapi 'kepercayaan itu, bahwa Aku telah katakan (ringkasan di dalam klausa berikutnya) adalah 'true'. Jika mereka masih sulit untuk memahami perkataan itu, paling tidak mereka akan percaya bukti dari mujizat (menggunakan kata $\epsilon \rho \gamma \alpha$ tetapi penekanan utama adalah mujizat) itu sendiri" (Carson, 2000). Morris menjelaskan

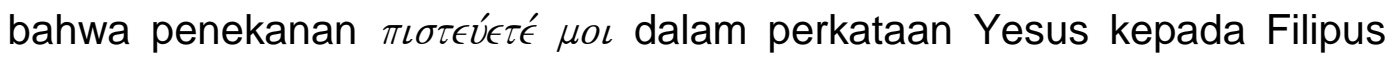
dan murid yang lain, bukan hanya percaya untuk kepada Dia, tetapi termasuk menyatakan bahwa Yesus adalah kebenaran (Morris, 1992).

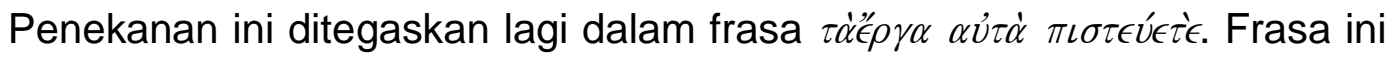
Yesus menggunakan kata kerja $\pi\llcorner\sigma \tau \epsilon u \in \epsilon \tau$ dalam bentuk imperatif yang berasal dari kata $\pi \iota \sigma \tau \epsilon u ́ \omega ́$ sama bentuk dengan kata kerja pertama. Hal ini menunjukkan bahwa pokok ini penekanannya sama penting dengan yang pertama. Kemudian di dalam teks ini, juga menekankan kata " $\rho \gamma \alpha$ dalam

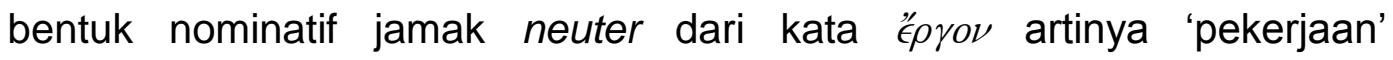
(Newman, 2016). Kata ini merupakan salah satu ciri khas Injil Yohanes yang nyata di dalam mujizat yang dilakukan oleh Yesus. Jika para murid belum memahami Yesus dengan benar bahwa Dia adalah Allah sendiri, maka melalui 'pekerjaan' yang dilakukan oleh Yesus menjadi tanda bagi para murid bahwa Allah bekerja melalui Yesus. 


\section{Makna Perkataan "akan melakukan pekerjaan-pekerjaan yang lebih besar dari ini” (Ayat 12)}

Di dalam ayat ini, sangat penting diperhatikan penekanan kata $\delta$ $\pi \iota \sigma \tau \epsilon \dot{\omega} \omega \nu$ (nominative tunggal maskulin partisip present aktif, dari kata $\pi \iota \sigma \tau \epsilon \dot{\omega} \omega$. artinya percaya, $\tau \dot{\alpha} \epsilon \rho \gamma \alpha$ (akusatif jamak neuter dari kata $\iota^{\epsilon} \rho \gamma o \nu$ )

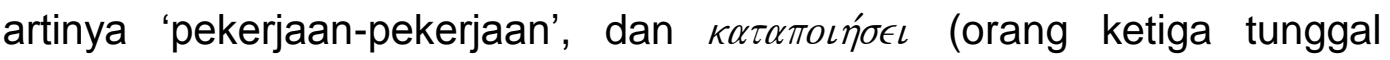
indikatif future aktif dari kata $\pi o\llcorner\epsilon ́ \omega$. yang artinya mengerjakan. (Newman, 2016). Ketiga kata ini menekankan bahwa apabila percaya kepada Yesus, maka para murid akan melakukan pekerjaan yang pernah dilakukan oleh Yesus, seperti Yesus: menyembuhkan orang sakit, menyucikan orang kusta, mengusir roh jahat, membangkitkan orang mati (Mat.10:8; Mrk.6:13; Luk.9:1-2) (Houwelingen, 1997).

Para murid seharusnya percaya kepada perkataan Yesus. Mereka sudah lama bersama-sama dengan Yesus sehingga pasti telah mendapat penjelasan lebih banyak tentang Yesus dibanding orang-orang Yahudi. Jika mereka percaya sungguh-sungguh, maka mereka dapat melakukan pekerjaan-pekerjaan yang pernah dilakukan oleh Yesus. Frasa di atas menunjuk kepada beberapa pekerjaan yang pernah dilakukan oleh Yesus. Penggunaan kata $\delta$ i $\pi \iota \tau \epsilon u ́ \omega \nu$ dalam bentuk partisip tidak hanya menunjuk kepada pengertian secara khusus yakni kepada para rasul tetapi juga kepada pengertian secara umum yakni "siapa saja orang-orang percaya" akan dapat melakukan "pekerjaan besar" tersebut. (Beasley-Murray, 
1999). Kruse juga menjelaskan perkataan Yesus di dalam teks di atas dengan menyatakan,

Frasa itu digunakan untuk menghubungkan dengan pelayanan yang pernah dilakukan olehYesus seperti percakapan dengan perempuan Samaria (4:34), menyembuhkan orang lumpuh di kolam Bethesda (5:20; 7:21), menyembuhkan orang buta sejak lahir $(9: 3,4)$, mujizat yang dilakukan oleh Yesus $(7: 3 ; 10: 25$, 32-33,3738), pengajaran Yesus, dan seluruh pelayanan Yesus (5:36) (Kruse, 2004, p. 229).

Perkataan Yesus itu menunjuk kepada setiap pekerjaan yang dilakukan-Nya dalam pelayanan. Tujuannya untuk mengingatkan para murid terhadap perbuatan-perbuatan yang besar itu, supaya mereka memahami bahwa Yesus adalah Allah sendiri yang telah melakukan pekerjaan-pekerjaan tersebut yang kemudian dipercayakan kepada mereka. Selain itu, frasa yang perlu dipahami di dalam teks ini adalah

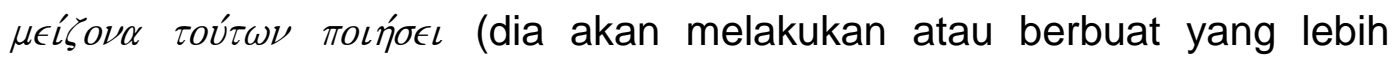
besar). Kata "̈ $p \gamma \alpha$ (akusatif jamak neuter artinya: pekerjaan-pekerjaan) masih lanjutan dari ucapan Yesus pada ayat 11 dan menunjuk kepada pekerjaan-pekerjaan yang telah dilakukan oleh Yesus (Carson, 2000). Lebih jauh Carson menjelaskan dua hal terkait dengan maksud frasa ini:

Pertama: menunjuk kepada klausa terakhir yakni 'karena Aku pergi kepada Bapa', kedua: merupakan paralel dengan fasal 5:20 dimana Bapa mengasihi Anak dan la menunjukkan kepada-Nya segala sesuatu yang dikerjakan-Nya, kedua penekanan ini, sama-sama merupakan suatu petunjuk bahwa murid Yesus akan melakukan pekerjaan besar karena Yesus pergi kepada Bapa (Carson, 2000, p.496). 
Para murid akan melakukan pekerjaan-pekerjaan besar seperti yang pernah dilakukan oleh Yesus. Namun demikian, bukan berarti mereka akan mengerjakan pekerjaan yang lebih besar dari pekerjaan yang pernah dilakukan oleh Yesus. Ketika Yesus pergi kepada Bapa, menunjukkan bahwa pekerjaan yang akan dilakukan oleh Yesus itu adalah pekerjaan yang sempurna atau pekerjaan yang jauh lebih besar.

\section{Makna kalimat "minta dalam nama-Ku, Aku akan melakukannya" (Ayat 13 \& 14)}

Dalam ayat 13 Yesus memberi himbauan kepada para murid supaya mereka meminta di dalam nama-Nya. Di sini tidak ada ucapan umum tentang doa dan pengabulan doa. Para murid yang mewakili guru mereka di dunia ini dalam melaksanakan pekerjaan-pekerjaan rasuli boleh memakai nama-Nya untuk memperkuat posisi mereka (Houwelingen, 1997) dalam menjalankan pekerjaan-pekerjaan tersebut.

Frasa ini merujuk khusus kepada doa para murid yang harus dinaikkan kepada kepada Yesus karena Yesus akan pergi kepada Bapa.

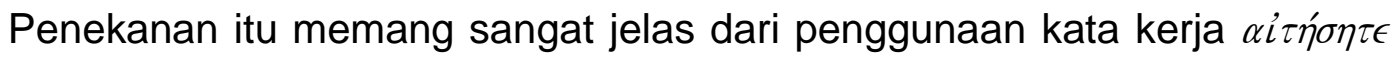

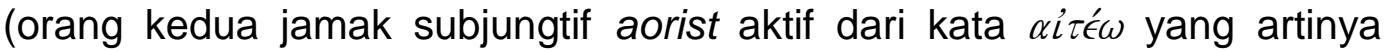
"kamu meminta") yang merujuk kepada para murid, bukan kepada orang orang-orang percaya secara umum. Doa ini sifatnya khusus untuk para murid karena mereka akan melakukan pekerjaan-pekerjaan yang dipercayakan Yesus setelah la pergi kepada Bapa. Para murid harus meminta kepada Yesus supaya mereka dimampukan dalam melakukan 
pekerjaan yang dipercayakan kepada mereka supaya Bapa dipermuliakan di dalam Anak. Tenney juga menjelaskan bahwa,

Maksud Anak ialah memperkenalkan Bapa kepada dunia, dan janji yang terkandung di dalam ayat 13 dan 14 tidak boleh ditafsirkan sebagai jaminan untuk memenuhi setiap tingkah seorang pendoa, tetapi lebih untuk menyelesaikan penyataan dari Bapa yang dimulai dengan inkarnasi, dan jawaban terhadap doa dalam nama Yesus adalah pekerjaan-pekerjaan Bapa yang terjadi melalui Dia. (Tenney, 1996, p. 211).

Doa para rasul yang dinaikkan kepada Yesus merupakan bagian penyataan penting bagi para murid supaya mereka memahami bahwa dengan melihat Yesus dan melakukan pekerjaan-pekerjaan yang dipercayakan kepada mereka, sama dengan melihat Bapa. Jika Anak dipermuliakan melalui pekerjaan-pekerjaan yang dilakukan oleh mereka sama dengan mempermuliakan Bapa. Kata kerja $\delta o \xi \alpha \sigma \theta \hat{\eta}$ bentuk orang ketiga tunggal subjungtif aorist pasif dari kata $\delta o \xi \alpha_{\zeta} \omega$ artinya "dipermuliakan" (Newman, 2016). Kata ini memberi penekanan yang sangat penting untuk memahami ungkapan Yesus pada frasa yang pertama mengenai himbauan Yesus terhadap para murid supaya meminta dalam nama-Nya. Namun maksud Yesus tersebut supaya Bapa dipermuliakan di dalam Dia. Michaels menyatakan, "bahwa Dia yang membawa pekerjaan-pekerjaan Bapa melalui pelayanan-Nya di dalam dunia yang secara berkelanjutan akan dikerjakan dalam bentuk pekerjaan yang "besar" dari surga melalui respon terhadap doa-doa para murid. (Michaels, 2010). Permohonan para murid kepada Yesus itu sama dengan 
meminta kepada Bapa karena pekerjaan yang dilakukan mereka juga merupakan pekerjaan Bapa. Di dalam permohonan itu, memperlihatkan kemuliaan Kristus, dengan tujuan untuk mempermuliakan Bapa.

Penekanan terakhir ungkapan Yesus dalam ayat 14 lebih menekankan tentang diri-Nya yang akan menjawab permohonan para murid. Kruse menekankan bahwa, "penggunaan nama Yesus tidak hanya menolong untuk menuju kepada Bapa, melainkan menekankan karakter hubungan yakni membawa kemuliaan Bapa-Nya." (Kruse, 2004, pp. 302303). Yesus semakin memperjelas kepada para murid bahwa hubunganNya dengan Bapa adalah hubungan yang sangat intim, sehingga dengan melihat Dia sama dengan melihat Bapa.

Jadi tindakan Yesus menjawab permohonan para murid, sebenarnya Dia sedang menyatakan kemuliaan Bapa-Nya di tengahtengah para murid, sehingga apa yang awalnya masih abstrak bagi para murid mengenai Bapa sekarang menjadi nyata bagi mereka. Dengan melihat Yesus dan pekerjaan yang dilakukan-Nya, sama dengan melihat Bapa. Jika para murid datang kepada Bapa, harus melalui Yesus Kristus karena segala sesuatu dari Bapa direalisasikan secara sempurna di dalam Dia (Michaels, 2010).

\section{KESIMPULAN}

Makna dialog Yesus dengan Filipus dalam teks Yohanes 14:8-14 dapat ditarik kesimpulan sebagai berikut: Pertama, kajian teks tentang 
permintaan Filipus (ay.8) sebagai perwakilan dari semua keinginan para murid dapat dianggap sebagai sebuah kegagalan para murid memahami pengajaran Yesus sekaligus memperlihatkan sebuah penolakannya atas ungkapan Yesus. Hal itu terlihat di dalam teks melalui adanya unsur pemaksaan kehendak untuk melihat penyataan seperti theofany dalam Perjanjian Lama. Permintaan Filipus itu dianggap mengandung unsur kegagalan karena para murid belum memahami secara benar jangkauan otoritas Yesus. Mereka berpikir bahwa dengan melihat Bapa seperti peristiwa theofany sudah cukup untuk percaya.

Kedua, cara Yesus memberi respon terhadap permintaan Filipus dapat dijadikan sebagai bukti bahwa para murid memang gagal memahami pengajaran Yesus. Oleh karena itu, untuk meluruskan pandangan para murid tersebut Yesus menyatakan tiga hal penting dalam teks ini yakni, (1) Menyatakan diri-Nya secara tegas sebagai kebenaran atau Allah sendiri. Hal itu diperlihatkan melalui penegasan Yesus "Barangsiapa telah melihat Aku, ia telah melihat Bapa." (2) Pekerjaan yang dilakukan oleh Yesus menjadi tanda bagi para murid bahwa Allah Bapa bekerja melalui Yesus. (3) Yesus memperlihatkan otoritasnya sebagai Allah dengan cara memberikan pekerjaan-pekerjaan yang lebih besar kepada para murid dalam pelayanan ketika Yesus sudah pergi kepada Bapa. Karena itu Yesus meminta para murid untuk menaikkan permohonan kepada-Nya dalam doa. Tindakan Yesus menjawab \begin{tabular}{l} 
permohonan doa para murid, sebenarnya Dia sedang menyatakan \\
\hline Yusuf L. M
\end{tabular} 
kemuliaan Bapa-Nya di tengah-tengah para murid, sehingga apa yang awalnya masih abstrak bagi para murid mengenai Bapa, sekarang menjadi nyata bagi mereka bahwa dengan melihat Yesus dan pekerjaan yang dilakukan-Nya, sama dengan melihat Bapa.

\section{DAFTAR PUSTAKA}

Barclay, W. (1996). Pemahaman Alkitab Setiap Hari Yohanes Ps 1-7. Jakarta: BPK Gunung Mulia.

Beasley-Murray, G. R. (1999). Word Biblical Commentary: John (2nd ed.). Nelson Reference \& Electronic, A Division of Thomas Nelson Publisher.

Blomberg, C. L. (2002). The historical reliability of John's gospel: issues \&amp; commentary. Illinois: InterVarsity Press.

Bruce, F. (2013). Tafsiran Alkitab Masa Kini 3. Jakarta: YKBK/OMF.

Carson, D. . (2000). The Gospel According to John (The Pilar New Testament Commentary). Grand Rapids: William B. Eerdman Publishing Company.

Hendriksen, W., \& Kistemaker, S. J. (2007). New Testament commentary. Grand Rapid, Michigan: Baker Book House.

Henry, M. (2010). Injil Yohanes 1-11. Surabaya: Momentum.

Houwelingen, P. H. R. Van. (1997). Johannes Het Evangelie van het Woord (Yohanes. Injil Firman). Kampen: Kok.

Köstenberger, A. J. (2004). John. Grand Rapid, Michigan: Baker Academic.

Kruse, C. G. (2004). The Gospel according to John: an introduction and commentary. Michigan: William B. Eerdmans Pub.

Michaels, J. R. (2010). The Gospel of John (The New International Commentary on the New Testament). Mchigan: Eerdmans Publishing Company. 
Morris, L. (1992). The Gospel According to Matthew. Grand Rapids: Eerdmans.

Newman, B. M. (2016). Kamus Yunani - Indonesia: Untuk Perjanjian Baru (22nd ed.). Jakarta: BPK Gunung Mulia.

O'Collins, G., Farrugia, E. G., \& Suharyo, I. (1996). Kamus Teologi. Yogyakarta: Kanisius.

Ridderbos, H. N. (2012). Injil Yohanes. Surabaya: Momentum.

Rienecker, F. (1980). A Linguistik Key to the Greek New Testament. Grand Rapids, Michigan: Zondervan Publishing House.

Sutanto, H. (2000). Hermeneutik: Prinsip dan Metode Penafsiran Alkitab. Malang: Literatur SAAT.

Tenney, M. C. (1996). Injil Iman : suatu telaah naskah Injil Yohanes secara analitis. Malang: Gandum Mas. 